\title{
Leader-Member Exchange Paradigm in RSUD Dr. Saiful Anwar Malang
}

\author{
Timotius F.C.W. Sutrisno ${ }^{1}$, Teofilus ${ }^{2}$, Diana Silaswara ${ }^{3 *}$, and \\ Nanduta Sito Rusmi ${ }^{4}$
}

\begin{abstract}
Research aims: The study was conducted to discuss the phenomenon of destructive leadership, cynicism, and employee performance that occurred at Dr. Saiful Anwar Malang Hospital. The purpose of this study is to look at the effect of destructive leadership on employee performance, the effect of cynicism on employee performance, and the moderation effect of cynicism on destructive leadership and employee performance at Dr. Saiful Anwar Malang Hospital. Design/Methodology/Approach: This study employed a partial least square (PLS) multivariate statistical technique. Sampling used a saturated sampling method, and the respondents were all employees of the Finance Department from 50 hospitals. The Likert scale was utilized as a measurement tool for the questionnaire.
\end{abstract}

Research findings: This study's results indicated that the destructive leadership variable positively and significantly influenced the employee performance variable. Based on the questionnaire results, it was known that Dr. Saiful Anwar Malang Hospital's employee performance had a positive nature in responding to the existence of destructive leadership so that performance was maintained.

http://journal.umy.ac.id/index.php/mb

DOI: 10.18196/mabis.v12i1.9041

\section{CITATION:}

Sutrisno, T.F.C.W., Teofilus, T., Silaswara, D., \& Rusmi, N.S. (2021). Leader-member exchange paradigm in RSUD Dr. Saiful Anwar Malang. Jurnal Manajemen Bisnis, 12(1), 19-29.

\section{ARTICLE HISTORY}

Received:

14 June 2020

Revised:

01 Aug 2020

01 Sep 2020

12 Sep 2020

Accepted:

10 Oct 2020

Theoretical contribution/Originality: Companies can develop strategies to anticipate destructive leadership and weaken cynicism because both attitudes can impact employee performance.

Practitioner/Policy implication: This research is expected to provide insight into leaders' and employees' behavior regarding the phenomenon of destructive leadership and cynicism to improve employee performance because companies with a positive culture can undoubtedly make employees comfortable so that they will do work optimally.

Research limitation/Implication: This research's implication shows that the employees' behavior in Dr. Saiful Anwar Malang Hospital was very good because employees could show positive attitudes even with pressures, such as destructive leadership and cynicism.

Keywords: Destructive leadership; Cynicism; Employee performance; LMX

\section{Introduction}

Martin, Thomas, Legood, and Dello Russo (2018) stated that the LeaderMember Exchange (LMX) is a process of developing relationships between leaders and team members below that have different LMX qualities. LMX is very important in the relationship of trust between leaders and subordinates because it improves the members' performance. 


\section{Sutrisno, Teofilus, Silaswara, \& Rusmi \\ Leader-Member Exchange Paradigm in RSUD Dr. Saiful Anwar Malang}

To help subordinates achieve better task performance, the leader needs to demonstrate sufficient trust in team members to ensure the leader-follower relationship's smooth and effective functioning (Byun, Dai, Lee, \& Kang, 2017).

Huertas-Valdivia, Gallego-Burín, and Lloréns-Montes (2019) affirmed that a good leader knows that a company or organization's employee performance level does not depend on only a few parties. A company with good employee performances will have a good company performance, showing that the existence of a relationship between individual or group performance with company performance is very close. The reason for the decline in employee performance is due to work conflicts (Sutrisno, 2019). The quality of employee performance is closely related to the leader's role in providing direction to subordinates. One role of a good leader is to motivate subordinates, but not all superiors want to do that.

One of the most common destructive leadership behaviors is bullying. Ahmad (2018) asserted that this unethical behavior could lead to a negative working environment. Three things cause destructive leadership. (1). The leader does not know anything about their employees, so he could not solve his company's problems. (2) The leader fails to create an innovative culture because he does not appreciate his employee efforts and miss out on the solutions to solve the problem because he does not develop innovative plans. (3) The leader does not accept criticism and suggestions from employees. (4) The leader fails to give motivation to employees.

Byun et al. (2017) added that conflict is one of the things that causes destructive leadership, namely leaders' behavior who violate the organization's interests by destroying the goals, tasks, resources, and satisfaction or welfare of their subordinates. Destructive leadership occurs, causing conflicts to employees called cynicism. Reichers, Wanous, and Austin (1997) stated that the factors influencing cynics include stress, lack of support and social recognition, lack of voice in the decision-making process, unequal distribution of power, and lack of communication. Moreover, Wanous, Reichers, and Austin (2000) stated that cynicism elements formed are: (1) Dispositional, namely the attitude of disliking policies that fail change. This error occurs due to a lack of motivation and ability. (2) Failure to change is made by an employee due to an unexpected event or outside management's control. (3) Pessimism happens because there is no party to blame for failure.

Creating and maintaining employee performance is an essential effort because, in addition to affecting the company's survival, it can also prevent cynicism. Kanwar, Singh, and Kodwani (2009) argued that satisfied employees would positively affect the company, such as increased efficiency and productivity. Companies with a positive culture, of course, can make employees comfortable so they will do the job optimally (Islam, Furuoka, \& Idris, 2020). In this case, Dr. Saiful Anwar Malang Hospital has inspired researchers about the magnitude of destructive leadership and cynicism's role in producing maximum employee performance. The purpose of this study is to look at the effect of destructive leadership on employee performance, the effect of cynicism on 


\author{
Sutrisno, Teofilus, Silaswara, \& Rusmi \\ Leader-Member Exchange Paradigm in RSUD Dr. Saiful Anwar Malang
}

employee performance, and the moderating influence of cynicism on destructive leadership and employee performance at Dr. Saiful Anwar Malang Hospital.

\title{
Literature Review and Hypotheses Development
}

The theoretical umbrella of this research is the Leader-Member Exchange (LMX) theory. This theory explains the exchange of roles between leaders and members and the exchange relationships that develop over time. According to Dienesch and Liden (1986), the LMX model is best seen as an operationalization of the role-making approach. It is based on the concept that developing roles in a close leader-employee relationship will result in a different definition of roles. The time constraints faced by all leaders in work strengthen this process because time pressure is the key for leaders to develop close relationships, even with only a few employees. Cheong, Yammarino, Dionne, Spain, and Tsai (2019) believe that LMX is formed from the relationship between superiors and employees due to the interaction and performance between them. Both parties share information, resources, time, and emotional effort that give employees the authority to make decisions and control the workplace. Moreover, Anand, Hu, Vidyarthi, and Liden (2018) also state that LMX focuses on assessing the relationships and interactions between superiors and subordinates. The closeness level of the relationship between leadership and subordinates shows an indication of LMX in the company. Meanwhile, some studies have shown that LMX focuses on a two-way relationship between leaders and employees and is an exchange relationship that aims to increase organizational success with a positive relationship between leaders and employees (Anand, Vidyarthi, \& Rolnicki, 2018; Gupta, Singh, \& Bhattacharya, 2017; Rockstuhl, Dulebohn, Ang, \& Shore, 2012).

The leader mostly treats all employees the same way, but, the boss can act differently from one employee to another. Thus, it is often said that a boss has a special person in an organization. Wibowo and Susanto (2013) identify that special people or trusted groups get more attention from superiors and receive certain privileges in an organization; this group is called in-group. Meanwhile, other groups of employees who get little time and appreciation from superiors or only have formal interactions are called out-groups. According to Pierce and Newstrom (2006), the high quality of LMX results in the employees getting the tasks as desired because they often communicate with superiors so that it influences organizational activities, receives a lot of support and rewards; however, all of that must be paid for working harder, sacrificing more a lot, and getting a higher risk in meeting the needs of superiors to achieve organizational goals than lowquality LMX employees.

According to Haq, De Clercq, and Azeem (2019) and Abugre (2017), leaders as individuals who have a high capacity for moral achievement are then combined with the tendency to consistency in accordance with individual morals; in this case, communication is a strategic factor in collaboration. Further, Nohe and Michaelis (2016) and Verbeke, Bagozzi, and Belschak,(2016) state that leadership is an individual contribution to the 


\section{Sutrisno, Teofilus, Silaswara, \& Rusmi \\ Leader-Member Exchange Paradigm in RSUD Dr. Saiful Anwar Malang}

knowledge used to obtain or find structured truths in the field of leadership, including introduction, acceptance, and use.

Specifically, Einarsen, Aasland, and Skogstad (2007) express that destructive leadership has two subordinate and organizational dimensions. Subordinates describe the superiors' behavior who violate the company's interests by weakening motivation, sabotaging employee performance's welfare with the behaviors of intimidation, harassment, and illtreatment. Meanwhile, destructive leadership is a behavior that violates company rules, including material or time, such as bribery, corruption, and carrying out goals that are contrary to the people in the company. Toxic leaders are negatively related to employee motivation and commitment but positively related to high turnover and the behavior of employees who intend to leave the company (Reed \& Bullis, 2009). Another perceived consequence is an increase in employee performance and health problems with the existence of such destructive leadership behaviors.

In their research, Durrah, Chaudhary, and Gharib (2019) define cynicism as an attitude consisting of three dimensions: beliefs, emotions, and effects. The first dimension is the belief that the organization experiences a slight decrease in integrity. The cynic in question is that employees lose trust in the organization and believe in the absence of justice, kindness, and sincerity in the organization. Second, cynicism is not only a small negative assessment of the organization but includes a strong emotional reaction. The third dimension is the tendency toward negative and sometimes disparaging behavior. The most apparent form of behavior is over-critical organizational expression.

Previous studies from Wanous et al. (2000) mention elements of the cynicism formation. First, dispositional is not liking the outcome policy for failure to change. This mistake can be based on a lack of motivation and ability. The second situation is the failure of employees' changes in the event of an unexpected event outside management's control. Thirdly, the pessimism is because there is no one to blame. Durrah et al. (2019) and Abugre (2017) argue that the negative impact of cynicism changes in environmental conditions. The gap between individual and employee expectations, the big difference between top management and lowest management, the complexity of work-life, and the difficulties of working time management that creates tension in employees support cynicism in the organization. Furthermore, based on the research (Abugre, 2017; Islam et al., 2020), they obtained a way to reduce and overcome cynicism in the workplace. The organization must do some things: (1) Do not discriminate and prevent employees from doing the same thing, and (2) All decisions made are purely based on merit and provide justice for all employees in the workplace.

In the research, Meswantri and Awaludin (2018) affirm that employee performance is the work achieved by employees in accordance with the authority and responsibility given by the organization to achieve the organization's vision, mission and goals legally, not violating the law and in accordance with morals and ethics. It also argues that performance is the quality and quantity achieved by an employee in completing tasks and responsibilities given to him. There are six employee performance indicators based on Pitafi, Kanwal, Ali,Khan, and Waqas Ameen (2018), including: 
1. Completing the job well

2. Giving more contribution to the company

3. Working hard at work

4. Doing work with innovative

5. Having a high enthusiasm at work

6. Having high quality to get the job done

Mullen, Fiset, and Rhéaume (2018) showed significant results between destructive leadership and employee performance. The study revealed that employee mental health disorders caused by destructive leadership affected employee performance. The crucial role in creating a healthy and safe workplace is not bad leadership behavior because it can damage the organization's health and safety (Teofilus, Sutrisno, Hongdiyanto, \& Wananda, 2020). Based on this, the study was conducted to prove that destructive leadership influences employee performance in Dr. Saiful Anwar Malang Hospital. Therefore, a hypothesis was developed, as follows:

$\boldsymbol{H}_{1}$. Destructive leadership has a significant effect on employee performance at Dr. Saiful Anwar Malang Hospital.

Research has shown that there is a relationship between destructive leadership and cynicism. According to Dobbs \& Do (2019), the study uncovered a positive and partially significant (simultaneous) and simultaneous (total overall) relationship between destructive leadership variables and cynicism. Thus, if a leader becomes destructive, it will cause cynicism to employees. In contrast, previous research by Rehan, Zafar Iqbal, Fatima, and Nawab (2017) regarding cynicism in organizations was seen as having a negative but significant relationship with employee performance. The research has proven that higher cynicism among employees would significantly affect their performance. Moreover, Biswas \& Kapil (2017) found that the level of negative attitudes, such as organizational cynicism at work, would further weaken when employees trusted actions, policies, and correspondence within their organization or company. Based on some of these studies, it is possible that cynicism moderates the influence of destructive leadership on employee performance in RSUD Dr. Saiful Anwar Malang. Based on this, a hypothesis was developed as follows:

$\mathrm{H}_{2}$ : Cynicism moderates the influence of destructive leadership on employee performance at Dr. Saiful Anwar Malang Hospital. 
The research construction model proposed in this research paper is:

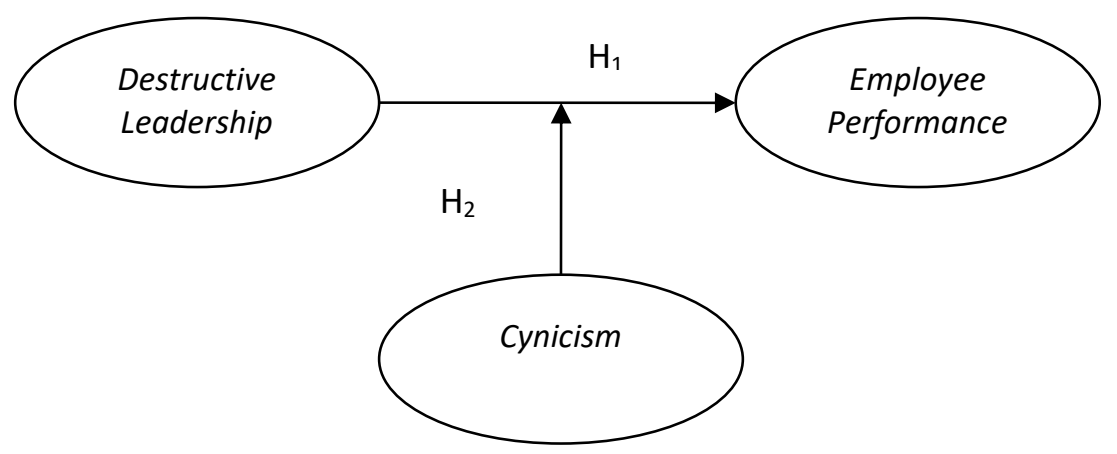

Figure 1 Research construction model

\section{Research Methods}

The research methodology used is quantitative research. Quantitative research studies the relationships between variables in the formulation of the problem set from a phenomenon and sees the possible connection (Sekaran \& Bougie, 2016). This research involved all financial section employees at Dr. Saiful Anwar Malang Hospital, which numbered 50 employees as the respondent and gave them a questionnaire for the data collection.

The scale employed to measure the questionnaire in this study was a Likert scale with five points: (1) strongly disagree, (2) disagree, (3) quite agree, (4) agree, and (5) strongly agree. The questionnaire distributed statements were compiled based on indicators adopted (taken) from several theoretical sources adjusted to employees' conditions at Dr. Saiful Anwar Malang Hospital.

This study used multivariate statistical techniques by comparing multiple dependent variables and multiple independent variables to analyze the data. Data processing utilized SmartPLS software. Using that software was because PLS could be used for research with small samples (Abdillah \& Jogiyanto, 2015). According to Abdillah and Jogiyanto (2015), the data validity is declared valid if outer loadings are more than 0.7 and the Average Variance Extracted value (AVE) is more than 0.5 ; it is called convergent validity test. The data are also said to be valid if the AVE for each variable or $\mathrm{R}^{2}$ and cross-loadings value is more than 0.7 ; the test is called the discriminant validity test. T-statistical values can be tested between the significant test of each variable. Based on the questionnaire results, the outer loading value obtained was more than 0.7, and the Average Variant Extracted (AVE) value was more than 0.5 in the convergent validity test. Meanwhile, AVE in each variable was less than $\mathrm{R}^{2}$, and cross-loading was more than 0.7 in the discriminant validity test. Ocean values between 0.5 to 0.7 cannot be removed because the AVE value reaches 0.5 (Abdillah \& Jogiyanto, 2015). The results showed the relationship between the paths of significant variables. The value of $R^{2}$ was used to measure changes in the independent 
and dependent variables. The higher the $\mathrm{R}^{2}$ value, the better it is for the research model. The T-statistic value was > 1.96; this value indicated that the relationship between variable paths was significant. According to Hair, Hult, Ringle, and Sarstedt (2014), reliability testing in PLS can use two methods: Cronbach Alpha and Composite Reliability. This study employed the composite reliability method. The composite reliability measurement method was utilized to determine whether the instrument was reliable or not and used the 0.6 limits.

\section{Results and Discussion}

Table 2 presents several indicators in this study, which had an outer loading value of $>$ 0.7 . It indicated that the indicators were valid and met discriminant validity. In this study, the composite reliability value was $>0.7$, so it was stated that the measuring instrument used in this study showed good and reliable results. Table 2 displays that the $\mathrm{R}^{2}$ value of the employee performance variable $(\mathrm{Y})$ was 0.427 . This value signified that the destructive leadership and cynicism variables only caused $42.7 \%$ of the employee performance variable conditions, while the remaining $57.3 \%$ was caused by other variables outside this research model.

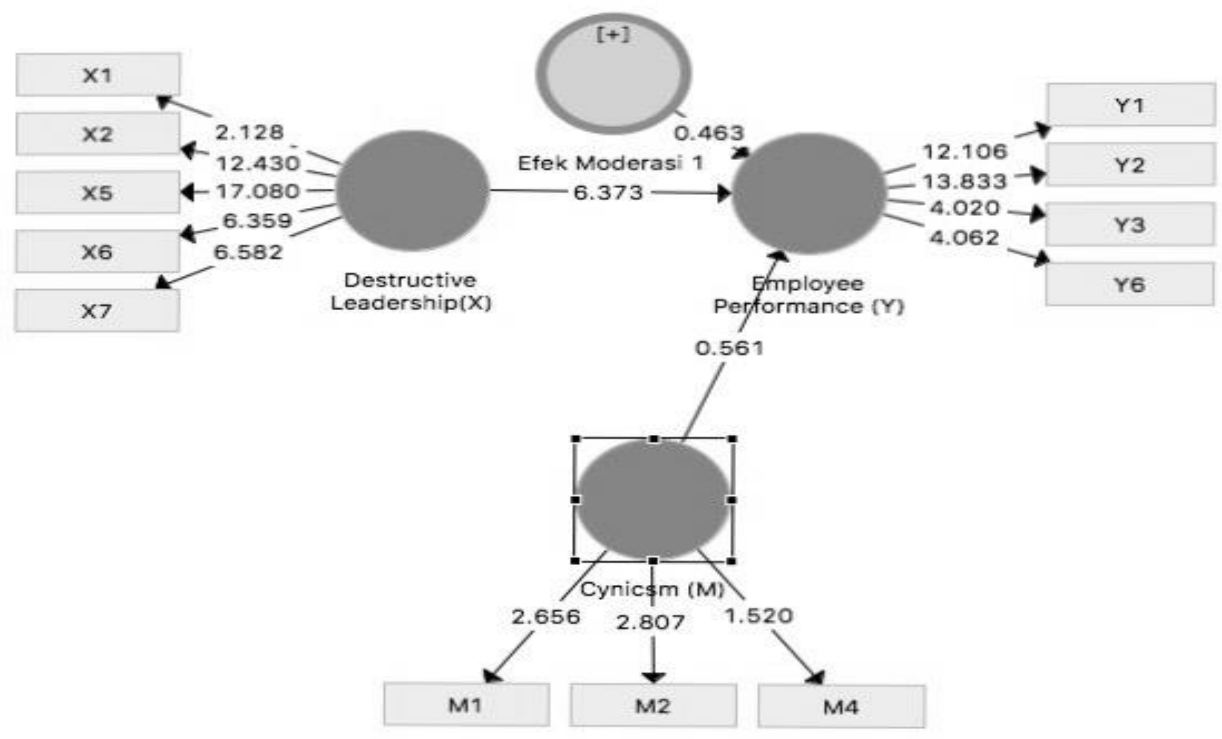

Figure 2 Analysis results of the construction model using the partial least square method

Based on the research results, several conclusions to answer the hypothesis can be drawn, as follows:

1. Hypothesis 1: Destructive leadership attitudes significantly influenced employee performance. However, in this study, especially in Dr. Saiful Anwar Malang Hospital, destructive leadership still had a significant positive effect. It denoted that all RSUD employees had positive characteristics in addressing destructive leadership attitudes to maintain employee performance.

2. Hypothesis 2: Destructive leadership with cynicism's attitude as moderation did not affect employee performance in RSUD Dr. Saiful Anwar Malang. Cynicism attitude did 


\section{Sutrisno, Teofilus, Silaswara, \& Rusmi \\ Leader-Member Exchange Paradigm in RSUD Dr. Saiful Anwar Malang}

not significantly influence or weaken employee performance at Dr. Saiful Anwar Malang Hospital. It becomes important because there is a need for a good mechanism to manage cynicism's attitude.

Table 2 Outer Loading, AVE, Composite Reliability \& R-Square

\begin{tabular}{cccccc}
\hline Variables & Indicators & Outer Loading & AVE & Composite Reliability & R-Square \\
\hline Destructive & X1 & 0.416 & 0,530 & 0,762 & \\
Leadership & X2 & 0.854 & & \\
& X5 & 0.878 & & \\
& X6 & 0.706 & & \\
Cynicism & X7 & 0.692 & & 0,642 \\
& M1 & 0.753 & 0,552 & \\
Employee & M2 & 0.890 & & 0,733 & \\
Performance & Y4 & 0.545 & & \\
& Y2 & 0.867 & 0,571 & \\
Moderating Effect & Y & 0.877 & & \\
\hline
\end{tabular}

Table 3 Path Coefficient and result model

\begin{tabular}{cccccc}
\hline Variables & $\begin{array}{c}\text { Original } \\
\text { Sample }\end{array}$ & $\begin{array}{c}\text { Sample } \\
\text { Mean }\end{array}$ & $\begin{array}{c}\text { Standard } \\
\text { Deviation }\end{array}$ & T Statistic & Results \\
\hline X-Y & 0,672 & 0,686 & 0,105 & 6.372 & Supported \\
M-Y & $-0,080$ & $-0,039$ & 0,142 & 0,561 & Unsupported \\
$\begin{array}{c}\text { Moderating } \\
\text { Effect-Y }\end{array}$ & 0,061 & 0,067 & 0,131 & 0.463 & Unsupported \\
\hline
\end{tabular}

\section{Conclusion}

This study revealed the effect of destructive leadership $(X)$ on employee performance $(Y)$ after the moderating variable in the inner model test remained significant (t-statistic = 6.372), with an original sample of 0.672 . It proved that the existence of destructive leadership in a company did not cause changes to employees. Based on the data processing results, the influence of destructive leadership $(\mathrm{X})$ on employee performance $(\mathrm{Y})$ was significant in moderation testing. It confirmed that $\mathrm{H}_{1}$ "destructive leadership has a significant effect on employee performance" was acceptable.

This study also showed that factors causing destructive leadership were when corporate leaders felt that achieving their personal goals thwarted by employees. While employees agreed that their leader's behavior has become more destructive over time, these same leaders might achieve good results and were considered by higher employees as excellent leaders. The effect of cynicism $(M)$ on employee performance $(Y)$ was proved insignificant in this study because after adding the cynicism (M) variable, the value of $Y$ decreased. It could be seen from the t-statistic results, which showed the value of 0.561 (t-statistic> 1.96), with the original sample -0.80 . This study verified that $\mathrm{H}_{2}$ "cynicism moderates the influence of destructive leadership on employee performance" was rejected. 


\section{Sutrisno, Teofilus, Silaswara, \& Rusmi \\ Leader-Member Exchange Paradigm in RSUD Dr. Saiful Anwar Malang}

The use of cynicism as a moderating effect has weakened the value of employee performance $(\mathrm{Y})$ because the processing results proved to be positive ( $\mathrm{t}$-statistic $=0.463$ ), and the original sample was 0.061 . However, it could be said that employee performance (Y) would be better if there were no moderator variables of cynicism. This study's results could be categorized as a potential moderation model since cynicism (M) did not affect employee performance $(\mathrm{Y})$, and the moderating variable did not affect employee performance $(\mathrm{Y})$.

The implication in this study showed that employees' behavior in Dr. Saiful Anwar Malang Hospital was very good since they could show positive attitudes even with pressures, such as destructive leadership and cynicism. Based on researchers' observations, employees had active and good behaviors because they always participated, worked together to complete tasks, and helped colleagues who had problems at work or non-work. The work provided by Dr. Saiful Anwar Malang Hospital was in accordance with employee competencies so that they could do it to the fullest.

Another implication of this study is that companies can develop strategies to anticipate destructive leadership and weaken cynicism because these attitudes could impact employee performance. One effort to reduce destructive leadership and cynicism is by conducting empowering leadership. Islam et al. (2020) state that a leader must understand the employees' motivation and behavior show an attitude of interest and care for employees, communicate effectively, and inspire their employees. Some indicators that have influences are respecting employees, developing employees, building community, and a delegation of power. These things will add to the employees' knowledge and experience, and leaders can avoid the attitudes of destructive leadership and cynicism. If these attitudes can be avoided, employee performance in the company will increase.

Based on the research results, several conclusions can be drawn destructive leadership attitudes significantly influenced employee performance; however, in this study, especially in Dr. Saiful Anwar Malang Hospital, destructive leadership still had a significant positive effect. It signified that all RSUD employees had positive characteristics in addressing destructive leadership attitudes to maintain employee performance. Cynicism's attitude did not significantly influence or weaken employee performance at Saiful Anwar Malang Hospital. It becomes essential since there is a need for a good mechanism to manage cynicism attitude. Cynicism attitude could not moderate destructive leadership's effect on employee performance in RSUD Dr. Saiful Anwar Malang.

\section{References}

Abdillah, W., \& Jogiyanto, H. (2015). Partial Least Square (PLS)-Structural Equation Modeling (SEM) dalam penelitian bisnis. Yogyakarta: CV ANDI OFFSET.

Abugre, J. B. (2017). Relations at workplace, cynicism and intention to leave. International Journal of Organizational Analysis, 25(2), 198-216. https://doi.org/10.1108/ijoa-09-2016$\underline{1068}$ 


\section{Sutrisno, Teofilus, Silaswara, \& Rusmi \\ Leader-Member Exchange Paradigm in RSUD Dr. Saiful Anwar Malang}

Ahmad, S. (2018). Can ethical leadership inhibit workplace bullying across east and west: Exploring cross-cultural interactional justice as a mediating mechanism. European Management Journal, 36(2), 223-234. https:// doi.org/10.1016/j.emj.2018.01.003

Anand, S., Hu, J., Vidyarthi, P., \& Liden, R. C. (2018). Leader-member exchange as a linking pin in the idiosyncratic deals - Performance relationship in workgroups. The Leadership Quarterly, 29(6), 698-708. https://doi.org/10.1016/j.leaqua.2018.07.005

Anand, S., Vidyarthi, P., \& Rolnicki, S. (2018). Leader-member exchange and organizational citizenship behaviors: Contextual effects of leader power distance and group task interdependence. The Leadership Quarterly, 29(4), 489-500. https://doi.org/10.1016/j.leaqua.2017.11.002

Biswas, S., \& Kapil, K. (2017). Linking perceived organizational support and organizational justice to employees' in-role performance and organizational cynicism through organizational trust: A field investigation in India. Journal of Management Development, 36(5), 696-711. https://doi.org/10.1108/JMD-04-2016-0052

Byun, G., Dai, Y., Lee, S., \& Kang, S. (2017). Leader trust, competence, LMX, and member performance: a moderated mediation framework. Psychological Reports, 120(6), 11371159. https://doi.org/10.1177/0033294117716465

Cheong, M., Yammarino, F. J., Dionne, S. D., Spain, S. M., \& Tsai, C.-Y. (2019). A review of the effectiveness of empowering leadership. The Leadership Quarterly, 30(1), 34-58. https://doi.org/10.1016/j.leaqua.2018.08.005

Dienesch, R. M., \& Liden, R. C. (1986). Leader-member exchange model of leadership: A critique and further development. Academy of Management Review, 11(3), 618-634. https://doi.org/10.5465/amr.1986.4306242

Dobbs, J. M., \& Do, J. J. (2019). The impact of perceived toxic leadership on cynicism in officer candidates. Armed Forces and Society, 45(1), 3-26. https://doi.org/10.1177/0095327X17747204

Durrah, O., Chaudhary, M., \& Gharib, M. (2019). Organizational cynicism and its impact on organizational pride in industrial organizations. Int J Environ Res Public Health, 16(7). https://doi.org/10.3390/ijerph16071203

Einarsen, S., Aasland, M. S., \& Skogstad, A. (2007). Destructive leadership behaviour: A definition and conceptual model. Leadership Quarterly, 18(3), 207-216. https://doi.org/10.1016/j.leaqua.2007.03.002

Gupta, V., Singh, S., \& Bhattacharya, A. (2017). The relationships between leadership, work engagement and employee innovative performance: Empirical evidence from the Indian R\&D context. International Journal of Innovation Management, 21(07), 1750055. https://doi.org/10.1142/S1363919617500554

Hair, J. F., Jr., Hult, G. T. M., Ringle, C. M., \& Sarstedt, M. (2014). A Primer on Partial Least Squares Structural Equation Modeling (PLS-SEM). SAGE Publication. Inc.

Haq, I. U., De Clercq, D., \& Azeem, M. U. (2019). Can employees perform well if they fear for their lives? Yes - if they have a passion for work. Personnel Review, 49(2), 469-490. https://doi.org/10.1108/pr-01-2019-0030

Huertas-Valdivia, I., Gallego-Burín, A. R., \& Lloréns-Montes, F. J. (2019). Effects of different leadership styles on hospitality workers. Tourism Management, 71, 402-420. https://doi.org/10.1016/j.tourman.2018.10.027

Islam, M. N., Furuoka, F., \& Idris, A. (2020). Employee championing behavior in the context of organizational change: a proposed framework for the business organizations in Bangladesh. Journal of Asia Business Studies, 14(5), 735-757.

https://doi.org/10.1108/jabs-01-2019-0019

Kanwar, Y. P. S., Singh, A. K., \& Kodwani, A. D. (2009). Work life balance and burnout as predictors of job satisfaction in the IT-ITES Industry. Vision: The Journal of Business 


\section{Sutrisno, Teofilus, Silaswara, \& Rusmi \\ Leader-Member Exchange Paradigm in RSUD Dr. Saiful Anwar Malang}

Perspective, 13(2), 1-12. https://doi.org/10.1177/097226290901300201

Martin, R., Thomas, G., Legood, A., \& Dello Russo, S. (2018). Leader-member exchange (LMX) differentiation and work outcomes: Conceptual clarification and critical review. Journal of Organizational Behavior, 39(2), 151-168. https://doi.org/10.1002/job.2202

Meswantri, \& Awaludin. (2018). Determinant of employee engagement and its implications on employee performance. International Review of Management and Marketing, 8(3), 36-44. Retrieved from https://www.econjournals.com/index.php/irmm/article/view/6365

Mullen, J., Fiset, J., \& Rhéaume, A. (2018). Destructive forms of leadership: The effects of abusive supervision and incivility on employee health and safety. Leadership and Organization Development Journal, 39(8), 946-961. https://doi.org/10.1108/LODJ-062018-0203

Nohe, C., \& Michaelis, B. (2016). Team OCB, leader charisma, and organizational change: A multilevel study. The Leadership Quarterly, 27(6), 883-895.

https://doi.org/10.1016/j.leaqua.2016.05.006

Pierce, J. L., \& Newstrom, J. W. (2006). Leaders and the leadership process: Readings, self-assessments and applications. New York: McGraw-Hill.

Pitafi, A. H., Kanwal, S., Ali, A., Khan, A. N., \& Waqas Ameen, M. (2018). Moderating roles of IT competency and work cooperation on employee work performance in an ESM environment. Technology in Society, 55, 199-208. https://doi.org/10.1016/i.techsoc.2018.08.002

Reed, G. E., \& Bullis, R. C. (2009). The impact of destructive leadership on senior military officers and civilian employees. Armed Forces and Society, 36(1), 5-18. https://doi.org/10.1177/0095327X09334994

Rehan, M., Zafar Iqbal, M., Fatima, A., \& Nawab, S. (2017). Organizational cynicism and its relationship with employee's performance in teaching hospitals of Pakistan. International Journal of Economics \& Management Sciences, 06(03). https://doi.org/10.4172/2162$\underline{6359.1000413}$

Reichers, A. E., Wanous, J. P., \& Austin, J. T. (1997). Understanding and managing cynicism about organizational change. Academy of Management Perspectives, 11(1), 48-59. https://doi.org/10.5465/ame.1997.9707100659

Rockstuhl, T., Dulebohn, J. H., Ang, S., \& Shore, L. M. (2012). Leader-member exchange (LMX) and culture: a meta-analysis of correlates of LMX across 23 countries. J Appl Psychol, 97(6), 1097-1130. https://doi.org/10.1037/a0029978

Sekaran, U., \& Bougie, R. (2016). Research methods for business (Seventh Edition ed.). WILEY.

Sutrisno, T. F. (2019). Relationship between total quality management element, operational performance and organizational performance in food production SMEs. Jurnal Aplikasi Manajemen, 17(2), 285-294. https://doi.org/10.21776/ub.jam.2019.017.02.11

Teofilus, T., Sutrisno, T. F., Hongdiyanto, C., \& Wananda, V. (2020). A Study of Indonesian online marketplace: Information processing theory paradigm. The Journal of Distribution Science, 18(8), 75-87.

Verbeke, W., Bagozzi, R. P., \& Belschak, F. D. (2016). The role of status and leadership style in sales contests: A natural field experiment. Journal of Business Research, 69(10), 41124120. https://doi.org/10.1016/j.jbusres.2016.03.040

Wanous, J. P., Reichers, A. E., \& Austin, J. T. (2000). Cynicism about Organizational Change. Group \& Organization Management, 25(2), 132-153. https://doi.org/10.1177/1059601100252003

Wibowo, N. C., \& Sutanto, E. M. (2013). Pengaruh kualitas Leader Member Exchange ( LMX) terhadap produktivitas kerja melalui kepuasan kerja dan komitmen organisasional pada PT . Nutrifood Surabaya. Agora, 1(1), 1-10. Retrieved from http://publication.petra.ac.id/index.php/manajemen-bisnis/article/view/1547 